\title{
Marker-Assisted Introgression of Pi-1 Gene Conferring Resistance to Rice Blast Pathogen Pyricularia oryzae in the Background of Samba Mahsuri
}

\author{
S. Vijay Kumar ${ }^{1}$, M. Srinivas Prasad ${ }^{1 *}$, R. Rambabu ${ }^{1}$, K.R. Madhavi ${ }^{1}$, \\ B. Bhaskar ${ }^{1,2}$, V. Abhilash Kumar ${ }^{1}$, R.M. Sundaram ${ }^{1}$, A. Krishna Satya ${ }^{3}$, \\ M. Sheshu Madhav ${ }^{1}$ and V. Prakasam ${ }^{1}$ \\ ${ }^{1}$ ICAR-Indian Institute of Rice Research, Rajendranagar, Hyderabad 500 030, \\ Telangana State, India \\ ${ }^{2}$ S.V. Agricultural College, Acharya N G Ranga Agricultural University, Tirupati 517 502, \\ Andhra Pradesh, India \\ ${ }^{3}$ Acharya Nagarjuna University, Nagarjuna Nagar, Guntur 522 510, Andhra Pradesh, India \\ *Corresponding author
}

\begin{abstract}
A B S T R A C T
Samba Mahsuri (BPT 5204) is one of the most popular and high yielding rice variety, grown extensively in India and other Asian countries also. However, it is highly susceptible to blast disease, caused by the fungal pathogen Pyricularia oryzae. The near isogenic line C101LAC derived from LAC23 possessing $\mathrm{Pi}-1$ gene was selected as donor, which is located on chromosome 11. The MAS useful to develop resistance line with highest recurrent parent genome within a short period. The C101LAC carrying resistant gene $\mathrm{Pi}-\mathrm{l}$ was crossed with Samba Mahsuri to generate the mapping populations. Foreground selection was carried out using linked marker RM 224 to identify the plants processing the target gene $(P i-1)$. The recovery of recurrent parent genome in each backcrossed generations was carried out through a set of 60 polymorphic SSR markers across the rice genome. Out of 123 positive plants for $\mathrm{Pi}-1$ gene in homozygous condition, a single plant (\#BL-40-21-86-28) was identified at $\mathrm{BC}_{2} \mathrm{~F}_{2}$ generation carrying the Pi-1 gene with maximum recovery of recurrent parent genome $(\sim 95.50 \%)$. This line was advanced through selfing and ancestry based selection for agro-morphological traits and also evaluated against blast on Uniform Blast Nursery (UBN). At $\mathrm{BC}_{2} \mathrm{~F}_{4}$ generation, five lines Viz., BL-40-21-86-28-19, BL-40-21-86-28-72, BL-40-21-86-28-101, BL-40-21-8628-208 and BL-40-21-86-28-256 with high level of resistance to blast were identified. A single line (\#BL-40-21-86-28-208) was found very similar to the recurrent parent in number of panicles per plant, panicle length and grain yield per pant. This line was selected for further advanced to release as NIL or used as future breeding programme for incorporation of blast resistance.
\end{abstract}

Keywords

Samba Mahsuri,

C1010LAC,

Pyricularia oryzae and Marker-

Assisted

Introgression

Article Info

Accepted:

14 December 2018

Available Online:

10 January 2019

\section{Introduction}

Rice, Oryza sativa (Linneaeus) is the one of most significant cereal crop. It cultivated under a wide variety of climatic conditions. India and China account for more than half of the world's rice areas, its contributor to global food security for the global population and 
consume more than three quarters of the global rice production (Hossain, 1997; Maclean et al., 2002). As a fact India population will likely to exceed 1500 million marked by 2050; to feed growing population, the production and productivity of rice must be increased. After green revolution rice production was increased in some areas to 6$10 \mathrm{t} /$ ha though many high yielding varieties. But the production was severely affected by a biotic (heat, drought and etc.) and biotic (diseases and insects) stresses. Among the biotic stresses, incidence of fungal diseases like blast is important it cause significant yield reduction up to $100 \%$ in favourable conditions. In most extreme cases blast disease can devastate rice fields and completely damage (Ou, 1985). Its effects aerial parts of rice plant mainly on leaves (leaf blast), necks (neck blast), panicles (panicle blast) and even roots in severe conditions (Prasad et al., 2012). Blast of rice caused by the fungal pathogen Pyricularia oryzae Cavara (teleomorphic Magnaporthe oryzae B. C. Couch). Currently the rate of increasing crop yield is decaling and need to focus on stability and sustainability of plant breeding efforts. Incidence and severity of the disease management mainly depends on cultural practices, fungicides, botanicals and bio-agents (Miah et al., 2013). Unfortunately, these methods are not very effective, majority of agricultural farmers are using fungicides/chemicals to control the diseases in agricultural crops (Bonman et al., 1992). The use of fungicides is additional expenditure to farmers and it affects the sustainable rice production and also very harmful to the ecology and environment. The resistant rice verities are a powerful tool to decrease the use of environmentally vicious pesticides.

Host plant resistance based on the hypothesis of gene-for-gene interaction is the cost effective and environmentally appropriate strategy to manage targeted trait i.e., blast of rice (Manandhar et al., 1992; Jia et al., 2000). However, $P$. oryzae isolate is highly variable and sometimes to overcome resistance genes, a small section of the virulent isolate spreads rapidly in rice cultivars (Wang et al., 1994; Fukuoka and Okuno, 2001). Whereas major resistance genes are very effective against $P$. oryzae isolate containing the analogous a virulent gene (Silue et al., 1992). During past decade, nearly 100 of resistant genes have been identified against blast and most of the gens are dominate except Pi21 gene, few are quantitative in nature and 20 are cloned and characterised (Zhou et al., 2004; Gowda et al., 2006; Sharma et al., 2012). Majority of the ' $R$ ' genes from landrace, of indica subspecies except $P i 9$ has originated from a wild species of $O$. minuta (Liu et al., 2002) and moreover, the majority of the ' $\mathrm{R}$ ' genes are race specific (Deng et al., 2006). Now a day's agricultural scientist/breeders are focusing to introgress the resistant genes into popular cultivars using new molecular approaches for durable resistance but sometimes all ' $R$ ' genes are not durable depending on climatic conditions.

Rice breeders are developing resistant varieties through conventional backcross breeding programme but it is tedious, time consuming (8-10 years from initiation to varietal release) and mostly dependent on environmental circumstances, painstaking and protracted for targeted trait/disease resistance. Now a day's PCR-based markers are used for accelerating the development of blast resistant rice cultivars, it is played an important role in rice improvement programme for increased demand will have to be met from less land, less number of labours and less number of fungicide spry (Hayashi et al., 2006; Latif et al., 2011). PCR-based markers have vast feasible to improve the efficiency and precision of traditional breeding through Master Assisted Selection (MAS) and it is more efficient, effective and reliable than 
conventional backcross breeding (Ragimekula et al., 2013). MAS are an effective approach to develop new cultivar by rapidly recovering the background quality characteristics of the recurrent parent and also allow the pyramiding of complex traits as well as quantitative trait loci (QTL), which is not possible through conventional backcross breeding but in some cases it will be more cost effective (Collard and Mackill 2008; Shanti et al., 2010; Miah et al., 2013). Recently, many rice varieties with complete resistance to blast have been developed through MAS i.e., Vikas et al., (2012) successfully introgressed two major blast resistance genes $\mathrm{Pi}-54$ and $\mathrm{Piz}-5$ into an elite Basmati variety, Hasan et al., (2015) resistant gene $\mathrm{Pi}-54$ into a Malaysian $c v$. MR 264 Rambabu et al., (2016) introgressed $\mathrm{Pi}-\mathrm{l}$ gene in the back ground of 'Swarna' variety and Vijay et al., (2018) also developed blast resistance in the background of Samba Mahsuri with Pi-54 gene. Similarly, the broad-spectrum of blast resistant gene $\mathrm{Pi}-\mathrm{I}$ was introgressed into mega variety BPT 5204 for resistance through marker assisted selection. However, the ability of MAS depends on the tight linkage between the marker and the target gene.

\section{Materials and Methods}

\section{Plant material and marker-aided backcross breeding}

The study on molecular markers analysis, phenotypic evaluation and agromorphological characters with regard to recurrent, donor parents (Samba Mahsuri and C101LAC) and progenies were conducted in the Department of Plant Pathology laboratory, greenhouse and paddy field, ICAR-Indian Institute of Rice Research, Hyderabad. Samba Mahsuri (BPT 5204) is popular indica variety because of good grain and cooking quality, medium slender grain type and a high yielding variety but highly susceptible to many diseases (blast, sheath blight and bacterial leaf blight) and pests (Stem borer, Leaf folder BPH and WBPH) considering this Samba Mahsuri used as recurrent parent to develop its adaptability to disease through introgression of disease resistance gene. Blast resistant donor C101LAC carrying $P i-1$ gene, till date there is no report about large-scale breakdown of resistance conferred by $\mathrm{Pi}-1$ from India or abroad, as per current reports $\mathrm{Pi}-1$ gene displayed resistance across multiple locations in India (DRR annual report, 200814) in view of C101LAC used as donor (Figure 1). $\mathrm{F}_{1}$ population were developed by hybridization between recurrent parent (Female parent) and donor parents (Male parent). The positive $\mathrm{F}_{1}$ plants carrying $\mathrm{Pi}-1$ gene was backcrossed individually to produce $\mathrm{BC}_{1} \mathrm{~F}_{1}$ plants. The desirable $\mathrm{BC}_{1} \mathrm{~F}_{1}$ plants are identified with maximum recovery of the recurrent parent genome (RPG) and again backcrossed with recurrent parent in independent backcross breeding programmes to develop the $\mathrm{BC}_{2} \mathrm{~F}_{1}$ generation. The gene positive plants were selected by following foreground selection in each backcross generation, and homozygous plants were identified at $\mathrm{BC}_{2} \mathrm{~F}_{2}$ generation and then pedigree selection was followed till $\mathrm{BC}_{2} \mathrm{~F}_{4}$.

\section{Foreground selection}

Markers used for selecting the target genes are simple sequence repeat marker (SSR), RM 224 gene linked to Pi-1 on chromosome 11 (Fuentes et al., 2008). Details of the primer sequence, chromosomal location and physical position are presented (Table 1).

\section{Genomic DNA extraction from rice leaves}

Genomic DNA was isolated using the microextraction procedure followed by Prabhu et al., (1998). Prior to extraction, $3-5 \mathrm{~cm}$ of young leaves were cut into small pieces and 
transferred to spot plate and then immediately $800 \mathrm{ml}$ of extraction buffer (CTAB) was added. After grinding, the sample was kept at $65^{\circ} \mathrm{C}$ for $30-40 \mathrm{~min}$. in water bath for incubation. Later equal volume of chloroform:isoamyl alcohol (24:1) was added into the tube and mixed well. It was centrifuged for $15 \mathrm{~min}$ at 13,000 rpm and then supernatant was transferred immediately to another fresh eppendrof tube by discarding the pellet. Later equal volume of ice chilled isopropanol was added and after mixing, these tubes were kept in $-20^{\circ} \mathrm{C}$ freezer for $1-2$ hours. After removing from the freezer tubes were shaken gently for 5-10 min and then the tubes were centrifuged for $10 \mathrm{~min}$ at 13,000 rpm and supernatant was discarded without disturbing the pellet. The pellet was washed with $100 \mu \mathrm{l}$ of $70 \%$ chilled ethanol and centrifuged for $5 \mathrm{~min}$ at $13,000 \mathrm{rpm}$. The supernatant was discarded and then pellet was air dried for 1 hour and suspended in 100$150 \mu 1$ of $1 \mathrm{X}$ TE buffer $(\mathrm{pH}$ 8.0) for long term storage $\left(-20^{\circ} \mathrm{C}\right.$ freezer). The isolated DNA was checked for its purity using nanodrop (Thermo Fisher, USA) for quantification and DNA quality check by $0.8 \%$ agarose gel electrophoresis at $90 \mathrm{~V}$ for $30 \mathrm{~min}$.

\section{PCR analysis using gene specific marker}

Gene specific markers were amplified by the PCR using forward and reverse primers. RM 224 primer was used for foreground selection of $\mathrm{Pi}-\mathrm{l}$ gene. PCR amplification was carried out with $2 \mu 1$ of $10 \mu 1$ mixture having $50-100 \mathrm{ng}$ of template DNA, $1 \mu 1$ of $10 \mathrm{X}$ PCR buffer, $0.5 \mu \mathrm{l}$ of $10 \mathrm{mM}$ dNTPs, $0.5 \mu \mathrm{l}$ of $10 \mathrm{pM}$ of each primers (forward and reverse) and $0.3 \mu 1$ of 3U Taq DNA polymerase (Genei, India). Amplification was performed by using thermocycler (AB Bio systems) described below (Table 2). The PCR products were resolved on 3\% agarose gel in 1X TAE buffer and stained with ethidium bromide $(0.5 \mathrm{pg} / \mathrm{mL})$ along with ladder and finally the
DNA profile visualized in a gel documentation system (Alpha Innotech, USA)

\section{Artificial screening of introgression lines for blast resistance}

At $\mathrm{BC}_{2} \mathrm{~F}_{4}$ generation, all selected IL's carrying $P i-1$ gene was evaluated in Uniform Blast Nursery (UBN) at ICAR-IIRR, Hyderabad using standard protocol followed by Prasad et al., (2011). The nursery bed layout consisted of $100 \mathrm{~cm}$ long single row of each entry spaced at $5 \mathrm{~cm}$. The susceptible check HR-12 was repeated after every five test entries and along the borders to ensure uniform disease spread. About 10-15 days after sowing (fourth leaf stage), the spores suspension of $P$. oryzae (IIRR-MSP-28 isolate) at concentration of $1 \times 10^{-5}$ conidia/ml were sprayed with the help of hand operator atomizer. Pathogen infection and disease pressure was increased by maintaining high relative humidity (93-99\%) by water misting and covering the nursery beds with polythene sheets during night time. The disease reaction was recorded 15 days after inoculation using standard evaluation system 0-9 scale (IRRI, SES, 1996) i.e. scores of 0-1 were considered as highly resistant, 2-3 were considered as resistant, 4-5 moderately resistant, 6-7 moderately susceptible and 8-9 highly susceptible respectively.

Evaluation IL's for yield and other agronomic parameters

Thirty-day old seedlings of the selected introgression lines (carrying $\mathrm{Pi}-1$ gene) at $\mathrm{BC}_{2} \mathrm{~F}_{4}$ were transplanted to field along with parents, which were evaluated to agronomic parameters at ICAR-Indian Institute of Rice research, Hyderabad $\left(17.3200^{\circ} \mathrm{N}, 78.3939^{\circ}\right.$ E) during wet season (Kharif) 2015.The lines were sown in randomized complete block design (RCBD) with two replications. Each entry was planted in a row length of $450 \mathrm{~cm}$ 
with spacing of 15 X $20 \mathrm{~cm}$. Each genotype was sown in five lines, and before entry parent lines (C101LAC and Samba Mahsuri) were sown. Recommended agronomic practices were followed during the field trial and observations were recorded for traits viz., yield per grain type (GT), plant (Y/P), number of productive panicles (PN), 1000 grain weight (TGW), grain per panicle (GP), panicle length (PL), plant height $(\mathrm{PH})$, days to maturity (DM) and days to $50 \%$ flowering (DFF) for their selection. Grain type was graded according to the classification given by Ramaiah, (1969) and other traits have been followed as per Sarawgi et al., (2013). The mean data after computing for each character was subjected to standard methods of analyses of variance followed by Panse and Sukatme, (1957).

\section{Results and Discussion}

\section{Introgression of $\mathrm{Pi}-1$ gene}

The $\mathrm{F}_{1} \mathrm{~s}$ plants were generated from the cross of recurrent parent Samba Mahsuri (BPT 5204) and donor parent C101LAC were evaluated for presence of the targeted resistance gene $P i-1$ by using the linked molecular marker RM 224. A total $96 \mathrm{~F}_{1}$ plants were generated and 51 plants were confirmed for their heterozygosity (Table 3; Figure 2). The true $F_{1}$ 's were identified through gene $P i-1$ amplification pattern. The true $\mathrm{F}_{1}$ plants were backcrossed with recurrent parent to produce the $\mathrm{BC}_{1} \mathrm{~F}_{1}$ 's. 87 heterozygous $\mathrm{BC}_{1} \mathrm{~F}_{1}$ plants were selected based on the molecular marker RM 224, agronomic traits and blast resistance. Of these one plant (\#BL-40-21) was selected and possessing maximum recovery of the recurrent parent genome $(\sim 76.66 \%)$ was identified by using 60 parental polymorphic SSR markers through background selection (Table 3). This line was backcrossed with recurrent parent Samba Mahsuri to generate $298 \mathrm{BC}_{2} \mathrm{~F}_{1}$ plants, were genotyped with the
RM 224 marker and 76 heterozygous plants were selected based on disease resistance. One plant i.e., \# BL-40-21-86 possessing maximum recovery of the recurrent parent genome ( $86.66 \%$; Figure 3$)$, these were then selfed and produced $489 \mathrm{BC}_{2} \mathrm{~F}_{2}$ populations. Among those plants, 123 plants were identified in homozygous condition and possessing dominant gene $P i-1$. Of these plants a single plant (\#BL-40-21-86-28) was possessing $\mathrm{Pi}-\mathrm{l}$ gene with blast resistant and maximum recurrent parent genome $(95.50 \%)$ was identified through background selection and also good agronomic performance (Table 3; Figure 4).

To identify the effectiveness of $P i-1$ gene in the background of the Samba Mahsuri, the selected homozygous plant (\#BL-40-21-8628) was forwarded to next generation by selfing and advanced through pedigree based methodology involving phenotypic based selection up to $\mathrm{BC}_{2} \mathrm{~F}_{4}$ generation. Finally, five promising advanced backcross derived lines were identified viz., BL-40-21-86-28-19, BL40-21-86-28-72, BL-40-21-86-28-101, BL40-21-86-28-208 and BL-40-21-86-28-256 (Table 4). These lines were screened for disease reaction along with parent's i.e., recurrent (Samba Mahsuri), donor (C101LAC) and highly susceptible check (HR-12). The donor parent C101LAC having $\mathrm{Pi}-1$ gene, showed resistance reaction with ' 0 ' disease score and the recurrent parent BPT 5204 showed $90 \%$ disease lesions occurrence on leaves with disease score '9', while all selected IL's viz., BL-40-21-86-28-19, BL40-21-86-28-72, BL-40-21-86-28-101, BL40-21-86-28-208 and BL-40-21-86-28-256 had blast resistance with disease score $1,1,1$, 1 and 2 respectively (Figure 5).

\section{Evaluation for yield and yield attributing traits}

The selected five ILs lines viz., BL-40-21-8628-19, BL-40-21-86-28-72, BL-40-21-86-28- 
101, BL-40-21-86-28-208 and BL-40-21-8628-256 (carrying $\mathrm{Pi}$-1gene) were evaluated for key agro-morphological traits and results showed that BL-40-21-86-28-208 had RPG of $95.50 \%$ grain yield slightly higher than $(21.1 \pm 0.3 \mathrm{gm})$ recurrent parent (i.e. BPT 5204; 20.0 $\pm 0.8 \mathrm{gm})$. Whereas other four IL's (BL-40-21-86-28-19, BL-40-21-86-28-72, BL-40-21-86-28-101 and BL-40-21-86-28256) possessing RPG of $95.19,94.45,94.98$ and 94.00 respectively and showed grain yield per plant more or equivalent to the recurrent parent (Table 5). Likewise, BL-40-21-86-28101 and BL-40-21-86-28-256 (80.3 $\pm 1.5 \mathrm{~cm}$ and $80.0 \pm 1.0$ ) were identified as taller than recurrent parent Samba Mahsuri (79.7 \pm 0.6$)$. A few significant variations were observed with respect to the number of panicles per plant and panicle length among the five ILs as compared to Samba Mahsuri (Table 5). The IL BL-40-21-86-28-19 and BL-40-21-86-28$208(18.5 \pm 0.5$ and $18.8 \pm 0.3)$ were identified having more thousand grain weight compare to recurrent parent $(18.3 \pm 0.6)$. Finally the IL BL-40-21-86-28-208 was found to be better than Samba Mahsuri because it had higher grain yield per plant and as well as disease (Figure 5).

Samba Mahsuri known as BPT 5204 is one among the popular variety of rice, known for its exlent grain quality and yield performance among farmers and consumers in India and other Asian countries but highly susceptible to disease of rice blast, is a major restraining factor for its performance of yield. The pathogen $P$. oryzae causes leaf blast, neck blast and panicle blast in rice resulting in severe yield loss up to 70-100 percent and effects grain quality also.

The present study was carried to transfer of blast resistance gene $P i-1$ into Samba Mahsuri through MAS (marker-assisted selection) using donors C101 LAC. It is obvious and proved to be the most useful gene $(\mathrm{Pi}-\mathrm{l})$ for broad spectrum resistance to various population of $P$. oryzae, being used in breeding programme in rice growing arias (Chen et al., 2001; Yu et al., 1991). Pi-1 gene was linked to RZ424 and RZ536 by RFLP markers, separated at a distance 19.6 and 14.0 $\mathrm{cM}$ and also mapped on the long arm chromosome 11 (Prasad et al., 2009; Yu et al., 1991). Fuentes et al., (2008) conducted mapping studies from intercrosses of C101LAC/C101A51 with RM 224, RM 5926 and RM $1233 *$ I markers were mapped 0.0.cM position to $\mathrm{Pi}-1$ and $\mathrm{Pi}-2$ genes. For foreground and background selection gene linked markers were used to select enviable lines. PCR based linked markers (Simple Sequence Repeats) are very useful for background selection because of chromosome specific, co-dominant, multi-allelic, highly informative and no need to restriction digestion (Swarup et al., 2006). In this study PCR-based RM 224 linked marker was used to identify true plants with $P i-1$ gene along with stringent phenotypic selection for faster recovery of the recurrent parent genome (RPG). Recurrent parent Samba Mahsuri is known for its astonishing quality and cooking character and the donor parent have many undesirable features like bold grained and dwarf featured but resistant to blast disease. Hence it was of most important to retain the recurrent parent genomic background simultaneously in accumulation to resistant gene introgression. This chore was envisaged by recurrent parent genome selection attached with stringent phenotypic selection for grain features of recurrent parent Samba Mahsuri. Rambabu et al., (2016) developed a new variety through marker assisted introgression in the background of Swarna by using Pi-1 gene with RPG $94.70 \%$. Similarly in this study also blast resistance introgress to Samba Mahsuri with RPG 95.50\%. Previously Abhilash et al., (2016) also developed a hybrid rice variety i.e. RPHR 1005 for blast and bacterial bight resistant along with RPG $93.4 \%$. 
Table.1 Marker Details used for introgression

\begin{tabular}{|c|c|c|c|c|c|c|}
\hline $\begin{array}{c}\text { Gen } \\
\text { e }\end{array}$ & $\begin{array}{c}\text { Mar } \\
\text { ker }\end{array}$ & $\begin{array}{l}\text { Linkage } \\
\text { group }\end{array}$ & $\begin{array}{l}\text { Genetic Map } \\
\text { distance (cM) }\end{array}$ & $\begin{array}{l}\text { Forward } \\
\text { sequence }\end{array}$ & $\begin{array}{c}\text { Reverse } \\
\text { sequence }\end{array}$ & Reference \\
\hline Pi-1 & $\begin{array}{l}\text { RM } \\
224\end{array}$ & 11 & 0 & $\begin{array}{l}\text { TTCGTTTTCCTTG } \\
\text { GTTAGTG }\end{array}$ & $\begin{array}{l}\text { ATTGGCTCCTG } \\
\text { AAGAAGG }\end{array}$ & $\begin{array}{l}\text { Fuentes } e t \\
\text { al., (2008) }\end{array}$ \\
\hline
\end{tabular}

Table.2 PCR profile

\begin{tabular}{|l|c|c|c|}
\hline \multicolumn{1}{|c|}{ Profile activity } & Temperature $\left({ }^{\circ} \mathbf{C}\right)$ & Time duration & No. of cycles \\
\hline Initial denaturation & $94{ }^{\circ} \mathrm{C}$ & $5 \mathrm{~min}$ & 1 \\
\hline Denaturation & $94{ }^{\circ} \mathrm{C}$ & $30 \mathrm{sec}$ & 35 \\
\hline Annealing & $55^{\circ} \mathrm{C}$ & $30 \mathrm{sec}$ & \\
\hline Extension & $72^{\circ} \mathrm{C}$ & $1 \mathrm{~min}$ & \\
\hline Final Extension & $72^{\circ} \mathrm{C}$ & $10 \mathrm{~min}$ & 1 \\
\hline Storage & $4{ }^{\circ} \mathrm{C}$ & $\alpha$ & 1 \\
\hline
\end{tabular}

Table.3 Details of foreground and background selection among the backcross derived plants from the cross BPT 5204/C101LAC

\begin{tabular}{|c|c|c|c|c|c|c|c|}
\hline \multirow{2}{*}{$\begin{array}{c}\text { S. } \\
\text { No }\end{array}$} & \multirow[t]{2}{*}{ Generation } & \multirow{2}{*}{$\begin{array}{l}\text { No. of } \\
\text { plants } \\
\text { screened }\end{array}$} & \multirow{2}{*}{$\begin{array}{c}\text { Foreground } \\
\text { Selection } \\
\text { Positive for } \\
\text { Pi-lgene }\end{array}$} & \multicolumn{3}{|c|}{ Background selection } & \multirow{2}{*}{$\begin{array}{c}\text { Best plant } \\
\text { selected based } \\
\text { on background } \\
\text { selection }\end{array}$} \\
\hline & & & & $\begin{array}{c}\text { SSRs } \\
\text { used } \\
\text { analyzed }\end{array}$ & $\begin{array}{c}\text { Polymorphic } \\
\text { SSRs, } \\
\text { homozygous for } \\
\text { R' allele }\end{array}$ & $\begin{array}{l}\text { (\%) recovery of } \\
\text { Recurrent } \\
\text { parent genome }\end{array}$ & \\
\hline 1 & $\mathrm{~F}_{1}$ & 96 & 51 & - & - & - & BL-40 \\
\hline 2 & $\mathrm{BC}_{1} \mathrm{~F}_{1}$ & 360 & 87 & 60 & 46 & $76.66 \%$ & BL-40-21 \\
\hline 3 & $\mathrm{BC}_{2} \mathrm{~F}_{1}$ & 298 & 76 & 14 & 6 & $86.66 \%$ & BL-40-21-86 \\
\hline 4 & $\mathrm{BC}_{2} \mathrm{~F}_{2}$ & 489 & 123 & 8 & 5 & $95.50 \%$ & BL-40-21-86-28 \\
\hline
\end{tabular}

Note: B=BPT 5204, L= C101LAC, BL= NILs of BPT 5204 X C101LAC

Table.4 Screening of the five selected $\mathrm{BC}_{2} \mathrm{~F}_{4}$ lines with $P$. oryzae

\begin{tabular}{|c|c|c|c|c|}
\hline \multirow{2}{*}{$\begin{array}{l}\text { S. } \\
\text { No. }\end{array}$} & \multirow[t]{2}{*}{ Designation } & \multirow{2}{*}{$\begin{array}{l}\text { Resistance gene } P \text { i-1genotyped by } \\
\text { using gene linked marker RM } 224\end{array}$} & \multicolumn{2}{|c|}{ Disease reaction with IIRR MSP-28 isolate } \\
\hline & & & Score & $\mathbf{R} / \mathbf{S}$ \\
\hline 1 & BPT 5204 & -- & 9 & $\mathrm{~S}$ \\
\hline 2 & C101LAC & ++ & 0 & $\mathrm{R}$ \\
\hline 3 & HR-12 & -- & 9 & $\mathrm{~S}$ \\
\hline 4 & BL-40-21-86-28-19 & ++ & 1 & $\mathrm{R}$ \\
\hline 5 & BL-40-21-86-28-72 & ++ & 1 & $\mathrm{R}$ \\
\hline 6 & BL-40-21-86-28-101 & ++ & 1 & $\mathrm{R}$ \\
\hline 7 & BL-40-21-86-28-208 & ++ & 1 & $\mathrm{R}$ \\
\hline 8 & BL-40-21-86-28-256 & ++ & 2 & $\mathrm{R}$ \\
\hline
\end{tabular}


Table.5 Details of agronomic performance of the parents and improved lines of Samba Mahsuri (BPT 5204) at $\mathrm{BC}_{2} \mathrm{~F}_{4}$ under field conditions

\begin{tabular}{|c|c|c|c|c|c|c|c|c|c|c|c|}
\hline $\begin{array}{l}\text { S. } \\
\text { No. }\end{array}$ & Designation & DFF & DM & $\begin{array}{c}\text { PH } \\
(\mathrm{cm})\end{array}$ & PN & $\begin{array}{c}\text { PL } \\
(\mathrm{cm})\end{array}$ & GP & $\begin{array}{c}\text { TG } \\
\text { W }\end{array}$ & $\mathbf{Y} / \mathbf{P}$ & $\begin{array}{c}\text { RP } \\
\text { G } \\
(\%) \\
)\end{array}$ & $\begin{array}{c}\text { Gr } \\
\text { ain } \\
\text { typ } \\
\text { e }\end{array}$ \\
\hline 1 & BPT 5204 & $\begin{array}{c}124.0 \\
\pm 1.0\end{array}$ & $\begin{array}{c}148.7 \\
\pm 0.6\end{array}$ & $\begin{array}{l}79.7 \\
\pm 0.6\end{array}$ & $\begin{array}{l}11.7 \\
\pm 0.6\end{array}$ & $\begin{array}{l}24.2 \\
\pm 0.8\end{array}$ & $\begin{array}{c}179.3 \\
\pm 0.6\end{array}$ & $\begin{array}{l}18.3 \\
\pm 0.6\end{array}$ & $\begin{array}{l}20.0 \\
\pm 0.8\end{array}$ & - & MS \\
\hline 2 & C101LAC & $\begin{array}{c}88.7 \pm \\
1.5\end{array}$ & $\begin{array}{c}108.0 \\
\pm 1.0\end{array}$ & $\begin{array}{l}80.7 \\
\pm 1.2\end{array}$ & $\begin{array}{c}9.3 \pm \\
0.6\end{array}$ & $\begin{array}{l}23.3 \\
\pm 0.6\end{array}$ & $\begin{array}{c}182.7 \\
\pm 2.5\end{array}$ & $\begin{array}{l}18.7 \\
\pm 0.6\end{array}$ & $\begin{array}{l}19.4 \\
\pm 0.6\end{array}$ & - & SB \\
\hline 3 & $\begin{array}{l}\text { BL-40-21- } \\
86-28-19\end{array}$ & $\begin{array}{c}124.3 \\
\pm 0.6\end{array}$ & $\begin{array}{c}145.7 \\
\pm 0.9\end{array}$ & $\begin{array}{l}78.3 \\
\pm 0.6\end{array}$ & $\begin{array}{l}10.7 \\
\pm 0.6\end{array}$ & $\begin{array}{l}24.0 \\
\pm 0.5\end{array}$ & $\begin{array}{c}180.3 \\
\pm 1.5\end{array}$ & $\begin{array}{l}18.5 \\
\pm 0.5\end{array}$ & $\begin{array}{l}20.1 \\
\pm 0.2\end{array}$ & $\begin{array}{c}95 . \\
19\end{array}$ & MS \\
\hline 4 & $\begin{array}{l}\text { BL-40-21- } \\
86-28-72\end{array}$ & $\begin{array}{c}125.0 \\
\pm 1.0\end{array}$ & $\begin{array}{c}147.3 \\
\pm 1.2\end{array}$ & $\begin{array}{l}79.0 \\
\pm 1.0\end{array}$ & $\begin{array}{l}11.0 \\
\pm 1.0\end{array}$ & $\begin{array}{l}23.8 \\
\pm 0.6\end{array}$ & $\begin{array}{c}179.0 \\
\pm 1.0\end{array}$ & $\begin{array}{l}18.2 \\
\pm 0.3\end{array}$ & $\begin{array}{l}20.6 \\
\pm 0.4\end{array}$ & $\begin{array}{l}94 . \\
45\end{array}$ & MS \\
\hline 5 & $\begin{array}{l}\text { BL-40-21- } \\
86-28-101\end{array}$ & $\begin{array}{c}124.0 \\
\pm 1.7\end{array}$ & $\begin{array}{c}146.3 \\
\pm 0.6\end{array}$ & $\begin{array}{l}80.3 \\
\pm 1.5\end{array}$ & $\begin{array}{l}11.7 \\
\pm 1.2\end{array}$ & $\begin{array}{l}23.7 \\
\pm 0.6\end{array}$ & $\begin{array}{c}180.0 \\
\pm 1.0\end{array}$ & $\begin{array}{l}18.0 \\
\pm 0.5\end{array}$ & $\begin{array}{l}20.3 \\
\pm 0.8\end{array}$ & $\begin{array}{l}94 . \\
98\end{array}$ & MS \\
\hline 6 & $\begin{array}{l}\text { BL-40-21- } \\
86-28-208\end{array}$ & $\begin{array}{c}123.0 \\
\pm 1.0\end{array}$ & $\begin{array}{c}144.3 \\
\pm 0.6\end{array}$ & $\begin{array}{l}78.7 \\
\pm 1.5\end{array}$ & $\begin{array}{l}12.0 \\
\pm 1.0\end{array}$ & $\begin{array}{l}24.2 \\
\pm 0.3\end{array}$ & $\begin{array}{c}182.7 \\
\pm 2.1\end{array}$ & $\begin{array}{l}18.8 \\
\pm 0.3\end{array}$ & $\begin{array}{l}21.1 \\
\pm 0.3\end{array}$ & $\begin{array}{c}95 . \\
50\end{array}$ & MS \\
\hline 7 & $\begin{array}{l}\text { BL-40-21- } \\
86-28-256\end{array}$ & $\begin{array}{c}125.3 \\
\pm 1.2\end{array}$ & $\begin{array}{c}146.0 \\
\pm 1.0\end{array}$ & $\begin{array}{l}80.0 \\
\pm 1.0\end{array}$ & $\begin{array}{c}9.7 \pm \\
0.6\end{array}$ & $\begin{array}{l}23.5 \\
\pm 0.5\end{array}$ & $\begin{array}{c}179.0 \\
\pm 1.0\end{array}$ & $\begin{array}{l}18.2 \\
\pm 1.0\end{array}$ & $\begin{array}{l}19.9 \\
\pm 0.8\end{array}$ & $\begin{array}{c}94 . \\
00\end{array}$ & MS \\
\hline
\end{tabular}

DFF: Days to 50\% flowering, DM: Days to maturity, PH: Mean plant height (cm), PN: No. of panicle per plant, PL: Panicle length $(\mathrm{cm})$, GP: Grain weight $(\mathrm{gm})$, TGW (gm): 1000 grain weight, RPG: Recurrent parent genome recovery (\%), MS: Medium Slender and "SB"- Short Bold.

Figure.1 Evaluation of donor parent C101LAC (DRR progress reports 2008-14)

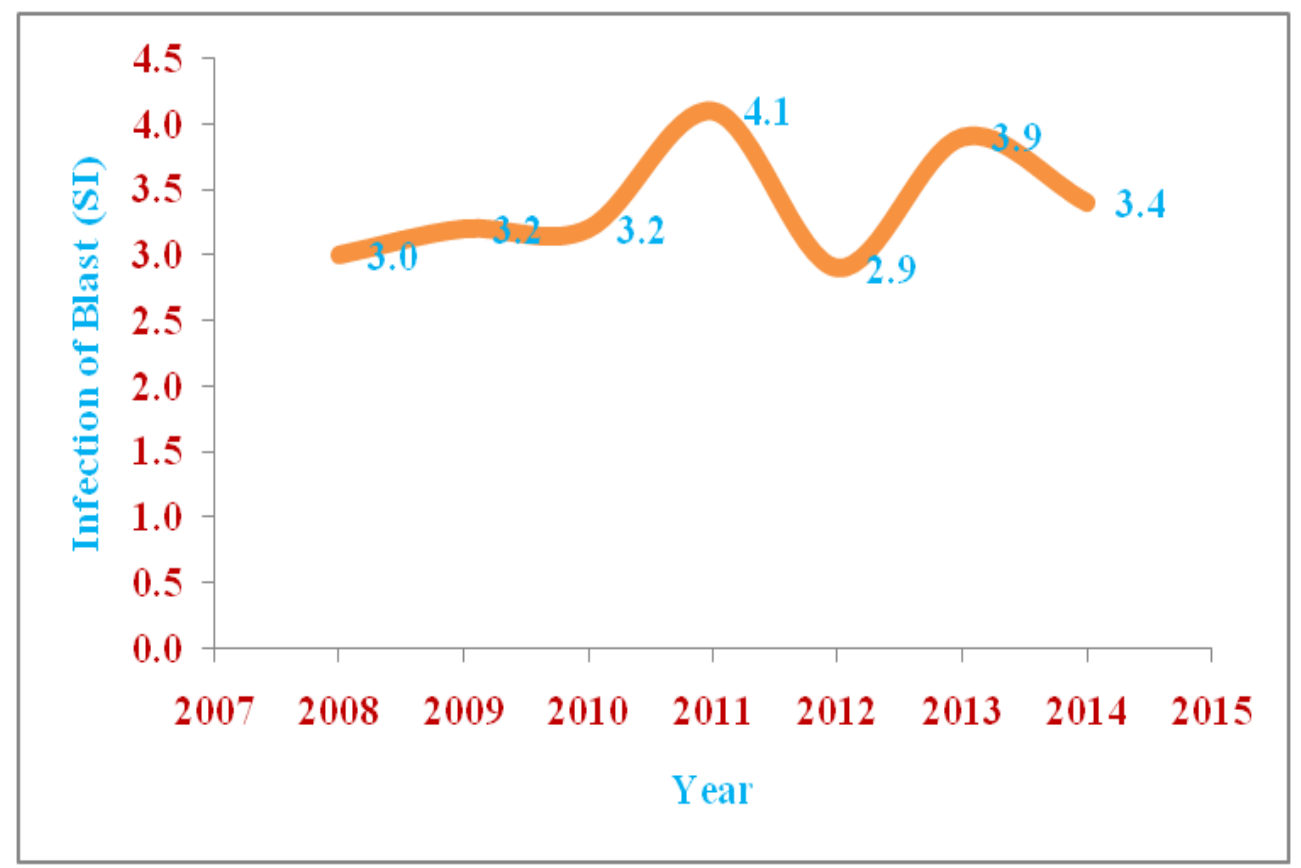


Figure. 2 Screening of $F_{1}$ plants with gene linked marker RM 224. The numbers represents the $F_{1}$ plants from the cross BPT 5204/C101LAC. Gel Lanes M: 50bp molecular weight ladder; BRecurrent parent 'BPT 5204 (Samba Mahsuri)', L - Donor parent 'C101LAC'; 26-50 - F1 plants, (line No's 27, 29, 30, 32, 35, 39, 40 and 48 'heterozygous positive plants' for $\mathrm{Pi}$-1gene)

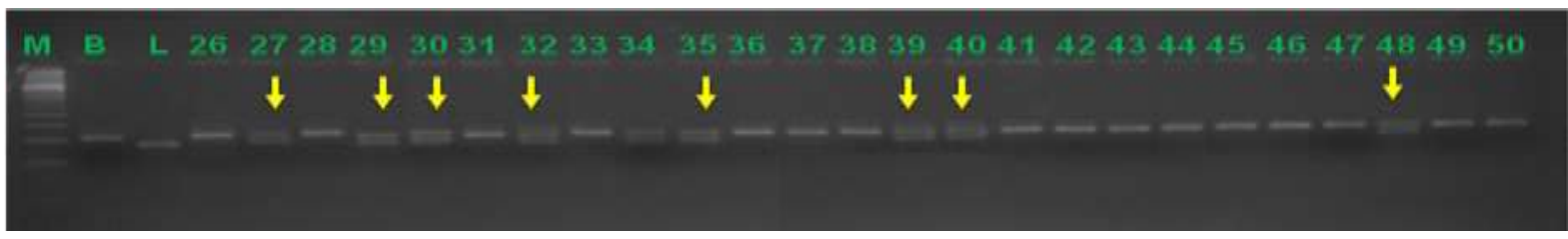

Figure.3 Screening of $\mathrm{BC}_{2} \mathrm{~F}_{1}$ plants with gene linked marker $\mathrm{RM} 224$. The numbers represents the $\mathrm{BC}_{2} \mathrm{~F}_{1}$ plants from the cross BPT 5204/C101LAC. Gel Lanes M: 50bp molecular weight ladder; B-Recurrent parent 'BPT 5204 (Samba Mahsuri)', L - Donor parent 'C101LAC'; 76-100 - F 1 plants, (line No’s 78, 79, 81, 86, 90, 91, 92, 93 and 100 'heterozygous positive plants' for Pilgene)

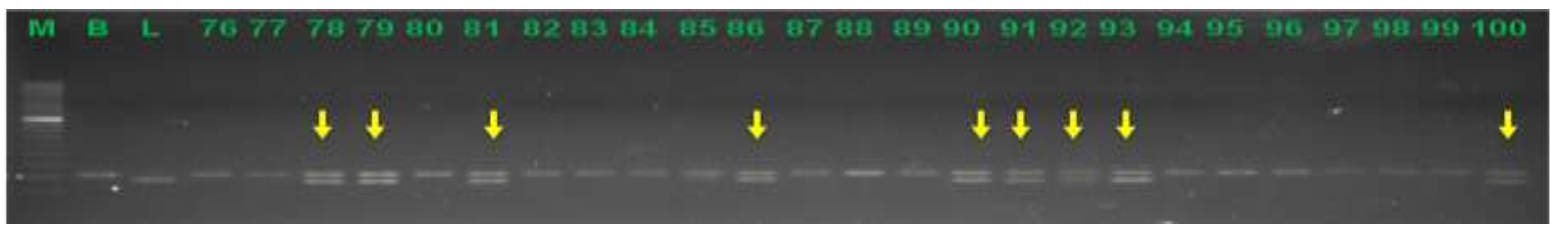

Figure.4 Screening of $\mathrm{BC}_{2} \mathrm{~F}_{2}$ plants with gene linked marker $\mathrm{RM} 224$. The numbers represents the $\mathrm{BC}_{2} \mathrm{~F}_{2}$ plants from the cross BPT 5204/C101LAC. Gel Lanes M: 50bp molecular weight ladder; B-Recurrent parent 'BPT 5204 (Samba Mahsuri)', L - Donor parent 'C101LAC'; 26-50 $\mathrm{F}_{1}$ plants, (line No's 28, 31, 33, 35, 41, 43, and 46 'homozygous positive plants' for $\mathrm{Pi}$-1gene).

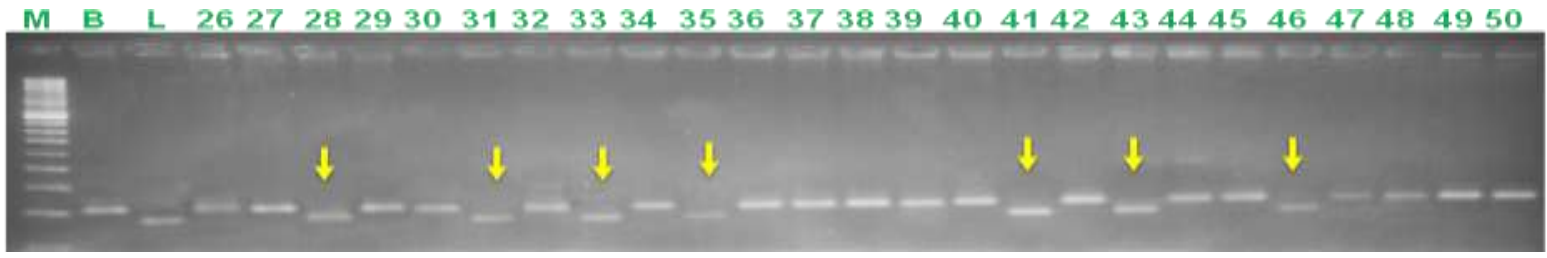

Figure.5 Phenotypic screening of $\mathrm{BC}_{2} \mathrm{~F}_{4}$ plants on Uniform Blast Nursery against blast disease. HR-12: Susceptible check, Samba Mahsuri (BPT 5204): Recurrent parent (susceptible) and C101LAC: Donor parent (highly resistant); IL-1 to IL6 (i.e., BL-40-21-86-28-19, BL-40-21-8628-72, BL-40-21-86-28-101, BL-40-21-86-28-208 and BL-40-21-86-28-256) introgressed lines.

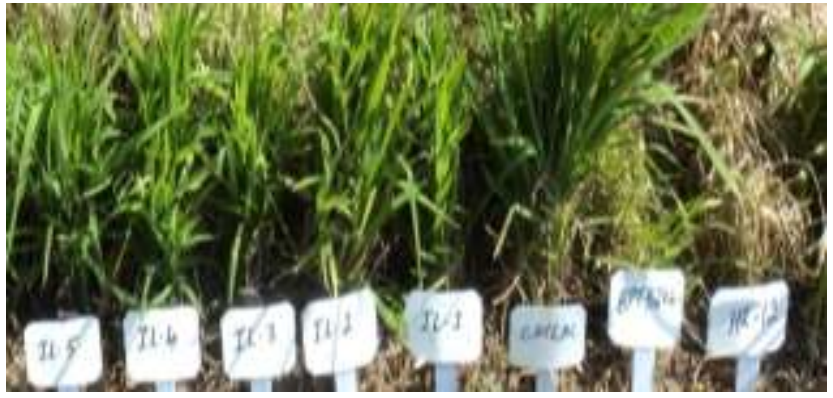


According to Alam et al., (2012) microsatellite polymorphic markers is an essential step in plant breeding application as it can differentiate between two different parental genotypes (recurrent and donor parents). Microsatellite markers are very preferable markers for plant breeding program due to well spread throughout rice genome and hyper variable (Miah et al., 2013). In this study 60 parental polymorphic SSR markers are used with $\sim 4$ polymorphic markers per each chromosome to the better exposure of each chromosome in genetic background selection. Ragimekula et al., (2013) reported that best primers selection was depended upon repeat number and location on all chromosomes. Similarly, Brinkman and Frey, (1977) also suggested it had surely resulted in restrictive the linkage drag to the regions close to the target genes. Hospital, (2001) suggested for background selection, a higher number of parental polymorphic markers are located on chromosome 11.

Earlier, Sundaram et al., (2008) also developed Improved Samba Mahsuri through MAS approach for bacterial leaf blight resistance by pyramiding $\mathrm{Xa21}$, xa13 and $x a 5$ genes. MAS was successfully employed to intrigues genes for resistance to various diseases in rice such as blast (Hittalmani et al., 2000; Singh et al., 2012; Madhavi et al., 2012; Hasan et al., 2015), bacterial leaf blight (Zhang et al., 2006; Basavaraj et al., 2010; Hari et al., 2013; Balachiranjeevi et al., 2015) and sheath blight (Wang et al., 2012), respectively by implementing an approach analogous to that used in the present study. The success of marker assisted selection depends up on tight linkage between the marker and the target gene. In this study $\mathrm{Pi}-\mathrm{I}$ gene was adopted a positive selection approach involving MAS for quick recovery of the RPG of Samba Mahsuri, therefore limiting the total number of backcrosses are just two. As a result, five improved breeding lines (BL-40-21-86-28-19, BL-40-21-86-2872, BL-40-21-86-28-101, BL-40-21-86-28208 and BL-40-21-86-28-256) of Samba Mahsuri possessing good plant type, excellent grain quality and medium-slender grain type along with blast resistant were identified. In this study, $\mathrm{BC}_{1} \mathrm{~F}_{1}, \quad \mathrm{BC}_{2} \mathrm{~F}_{1}$ and $\mathrm{BC}_{2} \mathrm{~F}_{2}$ population were observed with the average RPG of $76.66 \%, 86.66 \%$ and $95.50 \%$ respectively and it proved the statement that percentage of RP genome was higher in MAS compared to conventional breeding program. The present study demonstrated that a few individual plants in three generations $\left(\mathrm{BC}_{1} \mathrm{~F}_{1}\right.$, $\mathrm{BC}_{2} \mathrm{~F}_{1}$ and $\mathrm{BC}_{2} \mathrm{~F}_{2}$ ) showed a complete recovery of RPG.

According to Khush et al., (1989) many of the blast resistant varieties are breakdown due to resistance conferred by a single gene. Still now there is no report about breakdown of $\mathrm{Pi}$ 1 gene in India. Homozygous improved breeding lines of Samba Mahsuri with Pi-1 gene (BL-40-21-86-28-19, BL-40-21-86-2872, BL-40-21-86-28-101, BL-40-21-86-28208 and BL-40-21-86-28-256) were identified at $\mathrm{BC}_{2} \mathrm{~F}_{4}$ for blast resistant. Earlier Gouda et al., (2012) also developed introgressed lines, which were shown resistant to blast and neck blast at high level of M.oryzae population in Karnataka state. Indian farmers and consumers are not accepting without good grain type, exlent cooking quality and yield of rice, if those lines resistant to biotic and a biotic stress (Sundaram et al., 2008). In this study the selected all five advanced lines were on par with recurrent parent with RPG range between 93.98 to $95.50 \%$. One line BL-4021-86-28-208 with 95.50\% RPG have found to medium slender grain like recurrent parent and highly resistant to blast. In conclusion, Samba Mahsuri (BPT 5204) was successfully improved blast resistance through MAS and it will be valuable for further future blast resistance breeding programmes. The developed blast resistant line will be released 
through AICRIP programme and consequently might be attracts attention from farmers struggling with blast and also it contributes for food security.

\section{Acknowledgments}

The authors are thankful to Indian Council of Agricultural Research (ICAR), New Delhi for providing financial assistance and The Director, ICAR-Indian Institute of Rice Research, Hyderabad for providing the facilities and also thankful to technical and filed staff of the Department of Plant Pathology, ICAR-IIRR, Hyderabad for their sustained help and cooperation during this work.

\section{References}

Abhilash Kumar, V., Balachiranjeevi, Ch., Bhaskar Naik, S., Rambabu, R., Rekha, G., Madhavi, K. R., Harika, G., Vijay, S., Pranathi, K., Hajira, S. K., Srivastava, A., Mahadevaswamy, H. K., Anila, M., Yugander, A., Aruna, J., Hari Prasad, A. S., Madhav, M. S., Laha, G. S., Viraktamath, B. C., Balachandran, S. M., Senguttuvel, P., Kemparaju, B., Ravindra Babu, V., Sundaram, R. M. and Prasad, M. S., 2016, Marker-assisted introgression of the major bacterial blight resistance gene, $\mathrm{Xa21}$ and blast resistance gene, Pi54 into RPHR-1005, the restorer line of the popular rice hybrid, DRRH3. $J$. Plant Biochem. Biotechnol., 25(4), 400409.

Alam, M. S., Salim, M., Moniruzzaman, M., Rashid, J. A. and Islam, M. M., 2012, Marker-assisted Foreground Selection for Identification of Salt Tolerant Rice Genotypes. Agriculture., 10: 1-8.

Balachiranjeevi, Ch., Naik, S. B., Abhilash, V., Akanksha, S., Viraktamath, B. C., Madhav, M. S., Hariprasad, A. S., Laha, G. S., Prasad, M. S., Balachandran, S. M., Neeraja, C. N., Satendra Kumar, M., Senguttuvel, P., Kemparaju, K. B.,
Bhadana, V. P., Ram, T., Harika, G., Mahadeva Swamy, H. K., Hajira, S. K., Yugander, A., Pranathi, K., Anila, M., Rekha, G., Kousik, M. B. V. N., Dilip Kumar, T., Swapnil, R. K., Archana Giri and Sundaram, R. M., 2015, Marker assisted Introgression of bacterial blight and blast resistance into DRR17B, an elite fine-grain type maintainer line of rice. Mol. Breed., 35: 151.

Basavaraj, S. H., Singh, V. K., Singh, A., Singh, A., Singh, A., Anand, D., Yadav, S., Ellur, R. K., Singh, D., Krishnan, S. G. and Nagarajan, M., 2010, Marker-assisted improvement of bacterial blight resistance in parental lines of Pusa RH10, a superfine grain aromatic rice hybrid. Molecular breeding, 26(2), pp.293-305.

Bonman, J. M., Khush, G. S. and Nelson, R. J., 1992, Breeding rice for resistance to pests. Annu. Rev. Phytopanol., 30: 507528.

Brinkman, M. A. and Frey, K. J., 1977, Yield component analysis of oat isolines that produce different grain yields. Crop Sci., 17: 165-168.

Chen, H. L., Chen, B. T., Zhanga, D. P., Xie, Y. F. and Zhang Q., 2001, Pathotypes of Pyricularia grisea in rice fields of central and southern China. Plant Dis., 8, 842850.

Collard, B. C. and Mackill, J., 2008. Markerassisted selection: an approach for precision plant breeding in the twentyfirst century. Philosophical Transactions of the Royal Society B: Biological Sciences, 363:557-572.

Deng, Y., Zhu, X., Shen, Y. and He, Z., 2006, Genetic characterization and fine mapping of the blast resistance locus Pigm(t) tightly linked to Pi2 and Pi9 in a broad-spectrum resistant Chinese variety. Theor. Appl. Genet., 113:705-713.

DRR progress reports, Crop Protection (Entomology and Pathology), 2008-2014, All India coordinated rice improvement programme (ICAR). ICAR-Directorate of Rice Research, Rajendranagar, Hyderabad - 500030. 
Fuentes, J. L., Correa-Victoria, F. J., Escobar, F., Prado, G., Aricapa, G., Duque, M. C. and Tohme, J., 2008, Identification of microsatellite markers linked to the blast resistance gene $P i-1(t)$ in rice. Euphytica, 160, 295-304.

Fukuoka, S. and Okuno K., 2001, QTL analysis and mapping of pi21, a recessive gene for Weld resistance to rice blast in Japanese upland rice. Theor Appl. Genet., 103:185190.

Gouda, P. K., Saikumar, S., Varma, C. M. K., Nagesh, K., Thippeswami, S., Shenoy, V., Ramesha, M. S. and Shashidhar, H. E., 2012, Marker assisted breeding of $P i-1$ and $P i z-5$ genes imparting resistance to rice blast in PRR78, restorer line of Pusa RH-10 Basmati rice hybrid. Plant Breeding, 132:61-69.

Gowda, M., Barman-Roy, S., Chatoo, B. B., 2006, Molecular mapping of a novel blast resistance gene Pi38 in rice using SSLP and AFLP markers. Plant Breed., 125:596-599.

Hari, Y., Srinivasarao, K., Viraktamath, B. C., Hari Prasad, A. S., Laha, G. S., Ahmed, I. M. D., Natrajkumar, P., Sujatha, K., Srinivasa Prasad, M., Manish Pandey., Ramesha M. S., Neeraja, C. N., Balachandran, S. M., Rani, N. S., Balachandra, K., Madan Mohan, K., Venkata, S., ArunSama, K., Hajira, S. K., Balachiranjeevi, C., Pranathi, K., Ashok Reddy., Seshumadhav, M. and Sundaram, R. M., 2013, Marker assisted introgression of bacterial blight and blast resistance into IR58025B, an elite maintainer line of rice. Plant Breed., 132(6): 586-594.

Hasan, N. A., Rafii, M. Y., Rahim. H. A., Ali. N. S., Mazlan, N. and Abdullah, S., 2015, Introgression of $P i-k h$ resistance gene into a Malaysian cultivar, MR 264 using marker assisted backcrossing (MABC). Int. J. Agric. Biol., 17: 1172-1178.

Hayashi, K., Yoshida, H. and Ashikawa, I., 2006, Development of PCR-based allelespecific and InDel marker sets for nine rice blast resistance genes. Theor. Appl.
Genet., 113:251-260.

Hittalmani, S., Parco, A., Mew, T. V., Zeigler, R. S. and Huang N., 2000, Fine mapping and DNA marker-assisted pyramiding of the three major genes for blast resistance in rice. Theor. Appl. Genet., 100:11211128.

Hospital, F., 2001, Size of donor chromosome segments around introgressed loci and reduction of linkage drag in markerassisted backcross programs. Genetics., 158: 1363-1379.

Hossain, M., 1997, Rice supply and demand in Asia: a socioeconomic and biophysical analysis. Vol. 1, IRRI, Dordrecht: Kluwer Academic Publishers, 263-279.

IRRI., 1996, Standard Evaluation System for Rice. $4^{\text {th }}$ Edn., International Rice Research Institute, Manila, Philippines. 52.

Jia, Y., McAdams, S. A., Bryan, G. T., Hershey, H. P. and Valent B., 2000, Direct interaction of resistance gene and avirulence gene products confers rice blast resistance. EMBO Journal, 19:40044014.

Khush, G. S., 1989, Multiple disease and insect resistance for increased yield stability in rice. In: Progress in irrigated rice research. Manila (Philippines): International Rice Research Institute. 7992.

Latif, M. A., Rafii, M. Y., Rahman, M. M. and Talukdar, M. R. B., 2011, Microsatellite and minisatellite markers based DNA fingerprinting and genetic diversity of blast and ufra resistant genotypes. $C R$ Biol., 334:282-289.

Liu, G., Lu, G., Zeng, L. and Wang, G. L., 2002, Two broad-spectrum blast resistance genes, $P i 9(t)$ and $P i 2(t)$, are physically linked on rice chromosome 6 . Mol. Genet. Genomics, 267:472-480.

Maclean, J. L., Dawe, D. C. and Hettel, G. P., 2002, Rice almanae: Source book for the most important economic activity on earth, IRRI, Manila, Philippines.

Madhavi, K. R., Srinivas Prasad, M., Sheshu Madhav, M., Laha, G. S., Madhan 
Mohan, K., Sundaram, R. M., Jahnavi, B., Vijitha, S., Rao, P. R. and Viraktamath, B. C., 2012, Introgression of Blast Resistance Gene $P i-k h$ into Elite indica Rice Variety Improved Samba Mahsuri. Indian Journal of Plant Protection, Vol. 40, No. 1, 52-56.

Manandhar, H. K., Shrestha, K. and Amatya, P., 1992, "Seed-borne diseases." Plant diseases, seed production and seed health testing in Nepal. Danish Government, Institute of Seed Pathology for Developing Countries, Copenhagen, Denmark, 59-74.

Miah G., Rafii, M. Y., Ismail, M. R., Puteh, A. B., Rahim, H. A., Asfaliza, R. and Latif, M. A., 2013, Blast resistance in rice: a review of conventional breeding to molecular approaches. Mol Biol Rep. 40:2369-2388.

Ou, S. H., 1985, Rice diseases, $2^{\text {nd }}$ edn. Commonwealth Mycological Institute, Kew, Surrey, pp 380.

Panse, V. G. and Sukhatme, P. V., 1957, Genetics and quantitative characters in relation to plant breeding. Indian $J$. Genet., 17: 312-328.

Prabhu, K. V., Somers, D. J., Rakow, G. and Gugel, R. K., 1998, Molecular markers linked to white rust resistance in mustard Brassica juncea. Theoretical and Applied Genetics, 97: 865870.

Prasad, M. S., Aruna Kanthi, B., Balachandran, S. M., Seshumadhav, M., Madhan Mohan, K. and Viraktamath, B. C., 2009, Molecular mapping of rice blast resistance gene $P i-1(t)$ in the elite indica variety Samba mahsuri. World $J$. Microbiol. Biotechnol., 25:1765-1769.

Prasad, M. S., Ladha Laxmi, D., Prakasam, V., Laha, G. S., Krishnaveni, D. and Viraktamath, B. C., 2012, Disease management in rice - A Reddy Reckoner. Technical bulletin No. 60, Directorate of Rice Research, Rajendranagar, Hyderabad-500 030, Andhra Pradesh, India.

Prasad, M. S., Madhav, M. S., Laha, G. S., Ladhalakshmi, D., Krishnaveni, D.,
Satendrakumar, M., Balachandran, S. M., Sundaram, R. M., Arunakanthi, B., Madhanmohan, K., Ratnamadhavi, K., Kumar, V. and Viraktamath, B. C., 2011, Rice Blast Disease and it's Management. Technical bulletin No. 57, Directorate of Rice Research, Rajendranagar, Hyderabad - 500 030, Andhra Pradesh, India.

Ragimekula, N., Varadarajula, N. N., Mallapuram, S. P., Gangimeni, G., Reddy, R. K. and Kondareddy, H. R., 2013, Marker assisted selection in disease resistance breeding. J. Plant Breed. Genet., 1: 90-109.

Ramaiah, K., 1969, Grain Classification page No. 629 - Rice Research in India, ICAR Publication, 1985.

Rambabu, R., Vijay Kumar, S., Abhilash Kumar, V., Madhavi, K. R., Aruna, J., Madhav, M. S., Ravindrababu, V. and Srinivas Prasad, M., 2016, Marker assisted introgression of durable blast resistant gene $\mathrm{Pi}-\mathrm{I}$ into popular Indica variety. International Journal of Current Research, Vol. 8, Issue, 05, pp.3027030275.

Sarawgi, A. K., Rao, S. L. V., Parikh, M., Sharma, B. and Ojha, G. C., 2013, Assessment of variability of rice (Oryza sativa L.) germplasm using characterization. Journal of Rice Research, 6(1).

Shanthi, M. L., Shenoy, V. V., Devi, G. L., Kumar, V. M., Premalatha, P., Kumar, G. N., Shashidbar, H. E., Zebr, U. B. and Freeman, W. H., 2010, Marker-assisted breeding for resistance to bacterial leaf blight in popular cultivars and parental lines of hybrid rice. J. Plant Pathol., 92: 495-501.

Sharma, T. R., Rai, A. K., Gupta, S. K., Vijayan, J., Devannaand, B. N. and Ray, S., 2012, Rice blast management through host-plant resistance: retrospect and Prospects. Agric Res., 1(1): 37-52.

Silue, D. J., Notteghem, L. and Tharreau, D., 1992, Evidence of a gene-forgene relationship in the Oryza sativa 
Magnaporthe grisea pathosystem. Phytopathol., 82:577-580.

Singh, V. K., Singh, A., Singh S. P, Ellur, R. K., Choudhary, V., Sarkhel, D S., Singh, S., Gopala Krishnan, M., Nagarajan, K. K., Vinod, U. D., Singh, R., Rathore, S. K., Prasanthi, P. K., Agrawal, J. C., Bhatt, T., Mohapatra, K. V. and Prabhu, Singh, A. K., 2012, Incorporation of blast resistance into "PRR78", an elite Basmati rice restorer line, through marker assisted backcross breeding. Field. Cro. Rese., 128: 8-16.

Sundaram, R. M., Vishnupriya, M., Biradar, R. S. K., Laha, G. S., Reddy, A. G., Rani, N. S., Sharma, N. P. and Sonti, R. V., 2008, Marker assisted introgression of bacterial blight resistance in Samba Mahsuri, an elite indica rice variety. Euphytica., 160: 411-422.

Swarup, K., Parida, K., Kumar, A., Dalal, V., Singh, N. K., Mohapatra, T., 2006, Unigene derived microsatellite markers for the cereal genomes. Theor. Appl. Genet., 112:807-808.

Vijay Kumar, S., Rambabu, R., Bhaskar, B., Madhavi, K. R., Srikanth, S., Prakasam, V., Sundaram, R. M., Sheshu Madhav, M., Subba Rao, L. V. and Srinivas Prasad, M., (2018), Introgression of durable blast resistance gene $\mathrm{Pi}-54$ into indica rice $\mathrm{cv}$. samba mahsuri, through Marker Assisted Backcross Breeding. Electronic Journal of Plant Breeding, 9 (2), 705-715.

Vikas, K. S., Atul, S., Singh, S. P., Ranjith, K. E., Vikas, C., Sarkel, S., Devinder, S., Gopala, S., Krishnan, M. N., Vinod, K.
K., Singh, U. D., Rathore, R., Prashanthi, S. K., Agrawal, P. K., Bhatt, J. C., Mohapatra, T., Prabhu, K. V. and Singh, A. K., 2012, Incorporation of blast resistance into "PRR 78", an elite Basmati rice restorer line through marker assisted backcross breeding. Field Crops Res., 128: 8-16.

Wang, G. L., Mackill, D. J., Bonman, J. M., McCouch, S. R., Champox, M. C. and Nelson, R. J., 1994, RFLP mapping of genes conferring complete and partial resistance to blast in a durably resistant rice cultivar. Genetics, 136:1421-1434.

Wang, Y., Pinson, S. R. M., Fjellstrom, R. G. and Tabien R. E., 2012, Phenotypic gain from introgression of two QTL, qsb9-2 and qsb12-1, for rice sheath blight resistance. Molecular breeding, 30, 293303.

Yu, Z. H, Mackill, D. J., Bonman, J. M. and Tanksley, S. D., 1991, Tagging genes for blast resistance in rice via linkage to RFLP markers. Theor. Appl. Genet., 81:471-476.

Zhang, J., Li, X., Jiang, G., Xu, Y. and He, Y., 2006, Pyramiding of $\mathrm{Xa} 7$ and $\mathrm{Xa21}$ for the improvement of disease resistance to bacterial blight in hybrid rice. Plant Breeding, 125:600-605.

Zhou, T., Wang, Y., Chen, J. Q., Araki, H., Jing, Z., Jiang, K., Shen, J. and Tian D., 2004, Genome-wide identification of NBS genes in japonica rice reveals significant expansion of divergent nonTIR NBS-LRR genes. Mol. Gen. Genomics, 271:402-415.

\section{How to cite this article:}

Vijay Kumar, S., M. Srinivas Prasad, R. Rambabu, K.R. Madhavi, B. Bhaskar, V. Abhilash Kumar, R.M. Sundaram, A. Krishna Satya, M. Sheshu Madhav and Prakasam, V. 2019. Marker-Assisted Introgression of Pi-1 Gene Conferring Resistance to Rice Blast Pathogen Pyricularia oryzae in the Background of Samba Mahsuri. Int.J.Curr.Microbiol.App.Sci. 8(01): 2133-2146. doi: https://doi.org/10.20546/ijcmas.2019.801.223 